\title{
A POW'S STORY
}

\section{Cpl. C.F. Aquadro*}

In the interest of authenticity, editing has been kept to a bare minimum. This narrative thus appears in virtually its original form, as written in secret, under difficult conditions. Terminology is often in the vernacular. Details of regiments, titles and place names may also have been changed in the interim. Editor.

I was serving with the 4 th Brigade, Signallers Company, in No. 1 Platoon attached to the U.M.R., Infantry of the 2nd S.A. Division, Garrison of Tobruk since March, 1942, until the 18th June, 1942, when Rommel made his last main assault on Tobruk, and the same day we were besieged, besieged for three days. On the 21 st of June, our C.O. General Klopper of Tobruk surrendered to the Germans unconditionally. That Sunday morning of the 21st June, we were ordered to destroy all the equipment we had, which we did thoroughly. At about 9 p.m. German Panzer Units rushed upon us, where we were holding a line on the central perimeter, and from there I was taken prisoner. I had a small valice packed with a change of clothing and shaving outfit, the remainder of my possessions I burnt. We were all lined up in three's about one thousand of us with not many German guards with automatic guns, and in the blistering heat we were marched from the perimeter to the aerodrome a distance of six miles. On this aerodome about 25000 prisoners were massed including officers, everybody mixed. The same day each prisoner was issued with 1 W.B. of water, 1 tin of our bully and two biscuits for the day. It is terribly hot and we have no shelter at all. We slept there in the open that night.

22nd June. Water very scarce, nearly dead of thirst. Rations for the day $\frac{1}{2}$ W.B. of water, 1 tin of bully and 1 biscuit. Note that the rations have already been decreased. Slept very cold that night, I only had an overcoat.

23rd June. They started moving us now at an average of 3000 to 4000 men per day. Rations today were $\frac{1}{2}$ W.B. water, 1 tin of bully and 2 biscuits. Water so scarce now that the men are trading their watches for 2 gallons of water to the German guards. The ration of water includes washing as well.

24th June. Very demoralizing day, dusty and rations the same as previous day. Germans brought us water in huge mobile water tanks, but for propaganda purpose only. While thousands

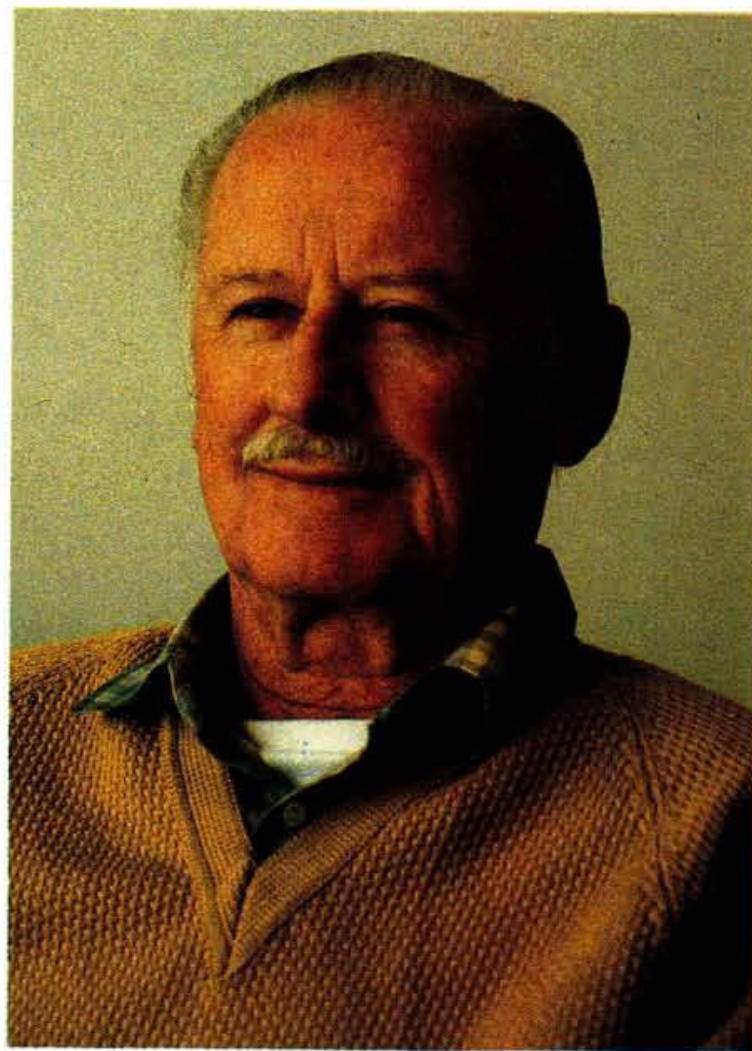

Mr Cyril Fiorintino ("Fury") Aquadro as he is today. A hale and hearty 70 years of age and living in active retirement in Bloemfontein. Photo: Eric McPherson

of us were scrambling and pushing each other around to try and get a mug of water the Germans were taking movie snaps of us. As soon as the snaps were taken, they pushed off, water and all.

25th June. We were divided into groups of 50 , for the purpose of rationing and moving. Received the usual rations, also a teaspoon of coffee between eight men, ersatz coffee at that, like brown mealie meal.

26th June. This morning early the Group 1 was put onto an Italian truck which holds fifty men, and moved off to the next transit camp, at Timemi, thirty miles away. The Itys (Italians) have r.ow taken us over from the Germans. There are about 6000 men in this camp, filthy, and millions 
of flies. No hygiene system at all. We are now on Ity rations, 1 tin of Ity bully (6 ozs) and 1 biscuit per man. (Inferior).

27 th June. The water position is better, there is a spring, and we are allowed to wash and drink as much as we like. Beginning to have a continuous hunger feeling now, the rations you receive you can eat before breakfast, but it has to last all day. An average of 50 men per day are being moved to hospital with dysentry and other similar diseases - no medicines and no doctors at all, anything you ask the Itys for, they say "When you get to Bhengasi".

28th June. Rations: 1 tin bully, 1 biscuit, 1 W.B. of water. As men are arriving daily from Tobruk, others are being moved forward up the line towards Benghasi. We are still sleeping in the open, no cover at all and at night it gets very cold.

29th June. Today we were taken to the spring about $\frac{1}{2}$ mile from camp, and had another good wash. Rations same as previous day. Nothing exciting all day.

30th June. Early this morning we were moved higher up the line, about 60 miles to Derna. A most uncomfortable trip, we had to stand all the way in a truck and arrived there after dark. Had no rations all day. When we arrived there, we each received one tin of bully only.

1st July. Very much better here, living in tents and the day started promisingly for living conditions. Received 1 cup of black bitter coffee, at least it is something warm and at lunch quite a good hot meal of macaroni and rice. After lunch we were taken down to the beach about 3 miles away for a swim. About 3000 of us marched down. No supper that night.

2nd July. Woke up and received a nice hot cup of coffee, black and bitter of course. A great scene today Mussolini arrived to inspect the prisoners. We believe he is on his way to Cairo ?? to meet Rommel at the Shepherds Hotel. He had a huge escort of about 30 motor cycles with machine guns. One British prisoner was shot immediately for showing Mussolini the "V" sign with his fingers, another was wounded. Rumours have now come through via the Italians, that the Germans have entered Alexandria. We just did not believe it, although it was possible. A German officer with a Yankee accent also came and told us that Alexandria had fallen, and that Rommel is expecting to be in Cairo within the next couple of days. We were dubious, stubborn I suppose like all S. Africans. Had no lunch today - went down for another swim, arrived back and had a supper of macaroni and rice again.

3rd July. A hot cup of coffee as usual and a hot meal for lunch and our usual swim, nothing else exciting, only we still hear about Alexandria being in German hands. (This was later proved to be propaganda.)

4th July. Worse luck no swimming today. Rations as usual. For the first time since being taken prisoners we each received 4 cig's, fortunately I am a non-smoker, so I gave mine to Harry. Harry is my brother-in-law; he was our Signal Sgt.

5 th July. Shortly after coffee this morning which is at $06 \mathrm{~h} 00$, we were told to be ready to move off at a moments notice. At $07 \mathrm{~h} 00$, we were given 1 tin of bully and 1 biscuit, put on troop carriers like cattle as usual and moved off. All day we stood, the worst journey yet but beautiful scenery all the way, travelled over 200 miles.

6 th July. 03h00, we arrived at Benghasi, hungry and tired, although looking forward to dawn, because we had heard such a lot about Benghasi and of the good food etc. Disappointed to find this place worse than was expected, it is like being back in the desert again. A huge camp partitioned into two camps, each holding about 14000 prisoners and a small camp to accommodate 2000 men, which they call the embarcation camp. It is from here we embark for Italy. The camp is about 1 mile from Benghasi Harbour. We were issued with a very small tent which has to hold 3 men. Our rations for the day were 1 bully and 2 biscuits, water scarce.

7th July. New ration scale: 1 tin bully and a loaf of bread the size of a hot cross bun, weight 200 grams (6 ozs), to try and keep your tummy full. We find it best to make soup with the bully. These rations we receive at 11.30 each morning.

8th July. In addition to our new rations, we also receive $\frac{1}{2}$ a cig. per man. At about $7.30 \mathrm{pm}$, the most encouragement we have had since we were taken prisoners, an air raid by our Liberators on the harbour. The German A.A. shot down one of our planes and we saw all the pilots bale out. They were not brought into our camp, so we could not get any first hand news. That is a big 


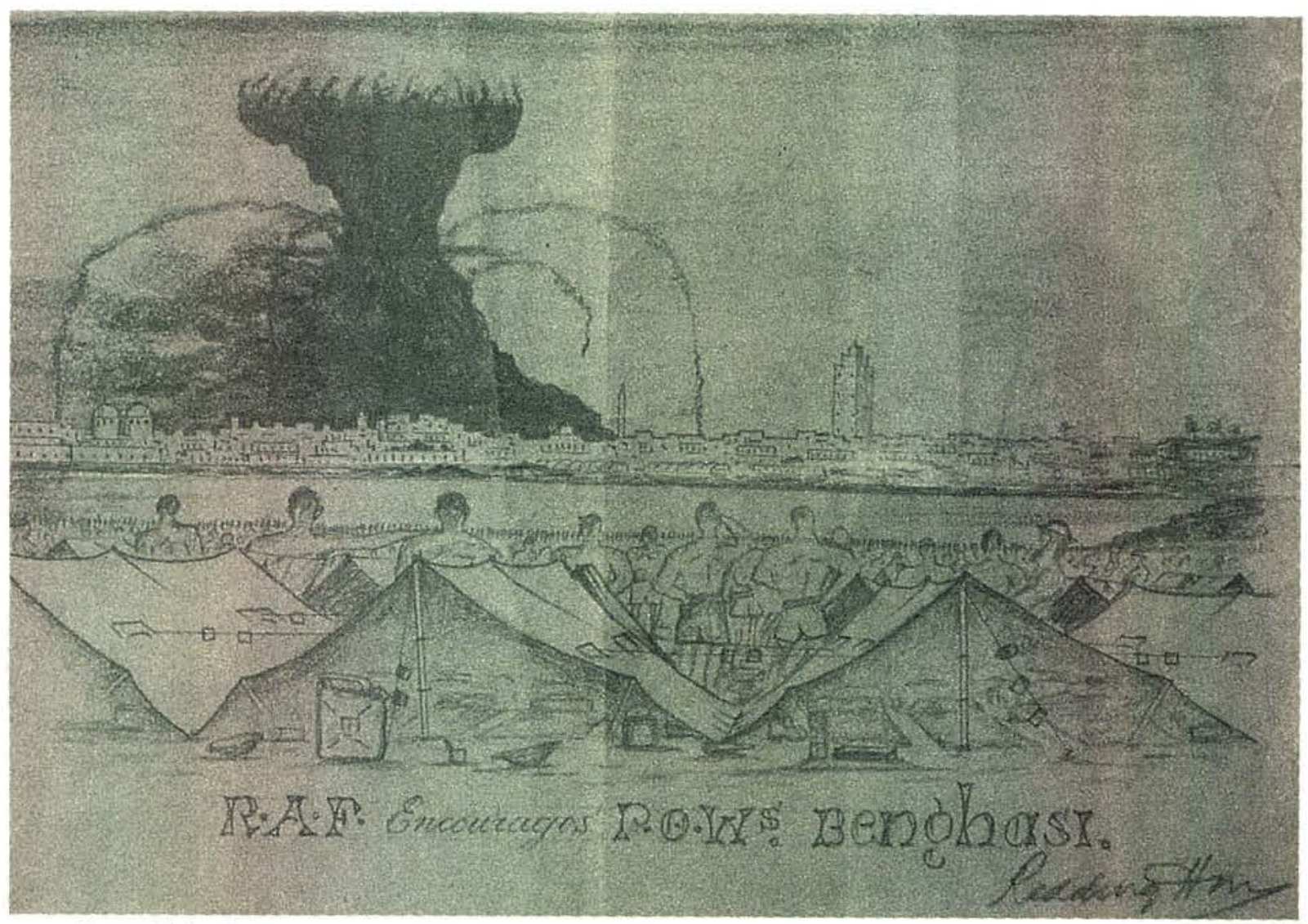

A pencil sketch done in the POW Camp at Benghazi illustrating a RAF bomber raid on the town of Benghazi.

game of the enemy to try and avoid us getting news.

9th July. The rations we are receiving seem to be our permanent ration scale. We protested about the rations and also not being able to write home. The only reply we get is that we are in a transit camp in the battle zone and until we get to Italy they cannot do more for us.

10th July. Usual rations, plus 4 cig's per man. This time I kept my cigs to buy wood so that I could warm my bully. We also received a little dry coffee enough to make one cup. We receive 1 W.B. of water per man per day both for washing and for drinking.

11th July. The three of us in the tent pool our rations and make two meals a day, not really meals but soup. No cig's today. In these camps there are a mixture of British, South Africans and Indians. No hygiene in camp at all, millions of flies.

12th July. Usual rations plus 5 cig's. Cig's are so scarce that they are sold amongst the boys at two shillings per cig. I bought wood with my cig's. We buy the wood from the Indians who are allowed to go out on fatigue duty everyday. They bring back wood with them to sell to the prisoners.

13th July. We received $\frac{1}{2}$ tin bully today plus a hot meal consisting of macaroni, peas and lentils - it was a good change.

14th July. Another exciting night, an air raid by our planes on the harbour. This really gives us encouragement, it is better than a hot meal. Received another 5 cig's.

15th July. Our rations arrived at 13 h00 hrs., we are starved and then they still have the nerve to bring the rations late. We are treated like dogs by the Itys. "Cenosi" Libyans are guarding us in the camp plus the Itys.

16th July. A luxury today $-1 \mathrm{lb}$ of cheese for a group of men, we each received a small cut of it. We were promised another hot meal for tomorrow; believe me it's something to look forward to.

17th July. Received a $\frac{1}{2}$ tin bully issued at 10.30 , and hot meal promised for 12.30. We waited all day but no meal arrived. With the Itys a missed meal is a lost ration. 
18th July. Received a $\frac{1}{2}$ bully, 1 bread and a hot meal plus 5 cig's. Another air raid on the harbour last night. Brave pilots, they dive down close to their targets through heavy A.A. barrage.

19th July. Sunday morning. We had a church parade with our own Padré. We had a large gatherii:g, afterwards the usual rations plus 5 cig's. I bought a tin of bully today for $10 \mathrm{cig}$ 's. It was good to have a little extra.

20th July. In addition to daily rations we receive $\frac{1}{2}$ lemon per man. Nothing exciting all day.

21st July. One of my tent-mate's exchanged his waterproof watch for 3 small loaves of bread and a $1 \mathrm{lb}$ tin of jam. He gave Harry and me a $\frac{1}{2}$ loaf each with some jam. It was marvelous to taste something sweet again. Usual ration plus $\frac{1}{2}$ cig's per man.

22nd July. The Itys brought mobile showers and fumigators for our clothing into the Camp. It was good to have a shower again. They took the names of our next-of-kin and said they would be notified from Rome that we were prisoners.

23rd July. We are now convinced that Alexandria was not captured. Prisoners brought in from $\mathrm{El}$ Alamein gave us the news up to a couple of days prior to their capture. Four cig's issued.

24th July. Rations are received earlier than usual plus a hot cup of soup. Everybody has the same complaint of weakness in their knees, dysentery is very bad, hundreds go down daily. I have been very fortunate up to now.

25th July. A 1000 men were moved from the adjacent camp into our camp, and rumours that the 6000 men in the next camp are on stand-by to move. Destination not known. I'm not keen to go from here despite the conditions. Hoping that there is a chance that I may be released.

26th July. Another shower today. I exchanged five cig's with an Ity for a spoonful of sauerkraut.

27th July. Six thousand men in the adjacent camp received registration cards, a sign of leaving. I shaved Harry's hair off. Lice are now spreading in the camp.

28th July. Another hot meal today. Harry bought each of us a blanket for $£ 1.00$ per blanket, from the chaps expecting to leave for Italy. Harry raffled a packet of 50 Springbok cig's. and got $£ 15.00$. A tin of jam was raffled by someone and raised the sum of $£ 75.0 .0$.

29th July. Woke up in the morning with the ringing of church bells in Benghasi, the celebration of Mussolini's birthday.

30th July. Three thousand eight hundred men travelled from adjacent camp to the docks tc embark for Italy. Three hundred and fifty men from our camp moved into the next camp. Usual rations.

31st July. We received 1 tin of our own good old bully between 4 men instead of the Ity's rations One hundred prisoners were brought into camp today, who say they were captured at El Alamein. Quite a lot of men have been moved lately. Our group is battling hard to stay, hoping for a chance of being released.

1st August. Another 3000 men were moved out of the adjacent camp to the docks. The figure has now been tremendously reduced. Altogether in both camps there are 7000 Europeans and 6000 Coloureds. Shipping is very scarce, otherwise we would have already been moved on. The Station Camp Commandant admits it.

2nd August. Usual rations. Rumours by the Ital ians that all prisoners will be moved within the next 6 days. Prisoners brought in from El Alamein say we are preparing for another Big Push. so we are keener than ever to remain here.

3rd August. Sixty nine more prisoners brought into the camp - captured at El Alamein - not too encouraging, but we are not giving up hope now. Usual rations.

4th August. Received extra water for washing clothing. Harry managed to go out on fatigue and brought back sume figs and torratoes for us. Oh Boy! what a treat, but only enough for one meal.

5th August. No sign of moving yet. Two men escaped last night, how they managed to escape is a miracle, anyway they were recaptured and punished. Punishment consists of being placed in a small dark room and at 12 noon being brought out into the hot sun and tied to a pole for about 3 hours without water and then taken back to the dark room. This happens every day for the period of the sentence. 
6th August. Usual rations but no coffee which means a lost ration. Another 2500 were moved from our camp to the adjacent camp.

7th August. We have been in this camp one month today. According to the Geneva Convention one is not supposed to remain in a transit camp longer than five days. Shipping is definitely the enemy's problem. Usual rations received.

8th August. Aclually, 2 hot meals today and 10 cig's. Nothing exciting. We have wonderful artists in the camp, also schemers and thieves. Men stealing boots and flogging them to the Itys for bread. This is a daily occurrence. When caught they are severely dealt with by our own Camp R.S.M.

9th August. A daylight raid on the harbour again, caught the German A.A. napping. Very strong wind blowing, one bomb dropped close to our Camp. Bought a blanket for $20 \mathrm{cig}$ 's, a real bargain. Flies are so bad you wave them away with one hand and eat fast with the other. You can have a hair cut for one cig in the Camp. Strong rumours that our forces have started an offensive. We are inclined to believe this because the Itys have increased our rations slightly and they are always issued on time.

10th August. The Itys are now putting another fence around our Camp, that makes it 6 fences around the camp. By the look of things we will still be here for sometime: Cig's are sold over the fence by the Itys at $80 \mathrm{cig}$ 's for a £1.0.0. They were later raised to 120 for a £1.0.0. Surprise raid by 40 Gestapo on the camp. An identification parade was called, no reason given, it took about 3 hours. Punishment takes place often. Two men found in possession of wire cutters, a serious offence, and were sentenced to four days imprisonment. Tied to a pole during the day in the heat. Received two days water only and the other two days bread only. One S. African was shot through the head last night by an Italian guard while trying to escape. We found him the following morning hanging dead over the fence.

11th August to 10th November. During this period rations have been the same. The only excitement being three big raids on the harbour. Direct hits were scored and 3 ships were burning for weeks. Only 3000 men are now left in camp, the others have been moved to Italy. We are now definitely convinced that the Allies have started an offensive. We can see the Jerrys retreating along the road to Tripoli and moving all their bulk equipment. No sign of moving yet. We are excited as we now have the chance of being released - rumours that our forces are at Mersa Matru

11th November. Very bad news this morning. We received orders to be ready to move by 2 p.m. Issued with one tin bully and 1 biscuit. At 2.30 p.m. we were marched down to the harbour. The name of the ship was the "MONREAL". We embarked and moved off at 6 p.m. We were all placed down in the hull except for a few upstairs; 3000 of us. The ship hugged the coast all the way to Tripoli, a most uncomfortable journey all the way. We still did not go to Italy.

12th November. Early this morning we disembarked at Tripoli harbour and were put on trucks and moved to another transit camp fifteen miles out of the city.

13th and 14th November. Rations received are a bit better. An Allied airman was brought into camp. He was shot down over El Agala while strafing Germans retreating from Benghasi. He said that Allies had occupied Benghasi onlv three days after we nad pushed oft - very heartbreaking, although we still stand a chance of being released here. Our bombers visited the Tripoli harbour three times today. Itys all in a flat spin.

15h November. Three hundred men were moved to the harbour for embarcation to Italy.

26th November. We were told to stand-by to move the following morning at 6 a.m.

27th November. At 7 a.m. we were given 1 tin bully and 1 biscuit and marched down to Tripoli harbour, a 15 mile march. In our condition it was hard work. We arrived at the harbour that afternoon, and were put onto a 4000 ton ship, right down in the hull. We were packed in like sardines together with Indians - no chance of lying down - too packed. We had just entered the hold when the air raid alarm sounded. Italian and German guards scattered for their lives. We were locked up, down in the dark hold and knowing how accurate our bombers could be, we did not see much hope for ourselves. We heard our planes but fortunately no bombs were dropped. Evidently a reccy. The "all clear" 


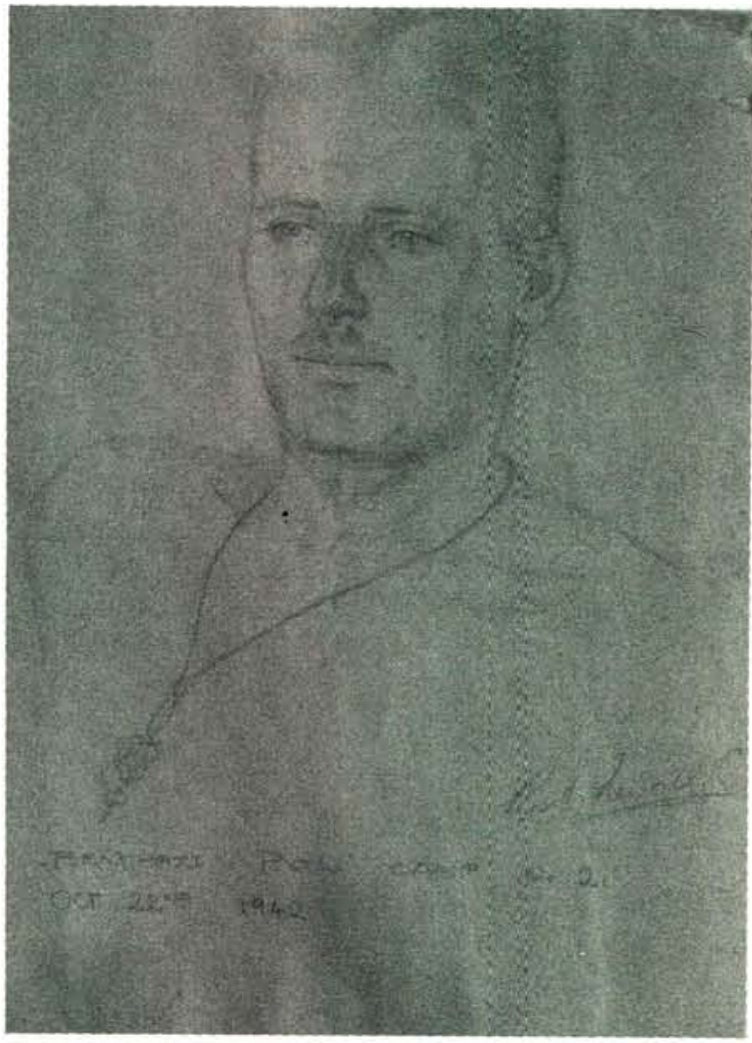

A pencil sketch of Cpl Aquadro done in Benghazi POW camp 47 years ago.

sounded, and at dark the ship sailed off. We zigzagged all the way, dodging British submarines. A terrible journey - no rations for two days as the bulk of our rations had been stolen.

29th November. At 6 a.m. we arrived in Naples Harbour. First thing we could see was Mount Vesuvius. We disembarked, were given something to eat and a hot shower. I was still so hungry that I traded my watch for bread. We were put onto railway trucks that night and travelled all night.

1st December. We arrived at Bari Station, having travelled across Italy. We marched from Bari Station through the town - with people gaping at us with open mouths. We covered three miles and arrived at our new camp - Camp PG75PM3450, but still a transit camp. A very nice camp to live in, brick buildings and electric lights, something we had not seen for six months and also slightly better food.

2nd December. This camp, including naval officers, consists of the following nationalities: $\mathrm{S}$. Africans, British, New Zealanders, Australians, Yugoslavé, Greeks, Poles and Russians. 3rd December. We received our first Red Cross parcel; one parcel of food for 15 men each day. From a canteen in the camp you could buy figs for 15 lire per kilo, and as our pay is 1 lire per

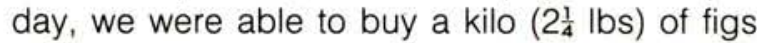
every 15 days.

Our ration scale - per man per day - approximately:

$\begin{array}{lc}\text { Macaroni } & 60 \text { grams (32 grams to the } \\ & \text { oz). } \\ \text { peas } & 30 \text { grams when available } \\ \text { oil } & 13 \text { grams } \\ \text { tomato puree } & 12 \text { grams } \\ \text { cheese - cooking } & 9 \text { grams } \\ \text { cheese - eating } & 40 \text { grams five times a week } \\ \text { meat } & 120 \text { grams }\end{array}$

This all amounts to two bowls of soup a day.

In the morning we receive 200 grams of bread and a cup of coffee sweetened. 21 cig's, $\frac{1}{2}$ a cigar and $\frac{1}{2}$ oz of tobacco once a week.

27th January. News received that Tripoli is in Allied hands. The only news we can depend on is news from new prisoners brought in. We also received a ration of English cig's, 30 per man per week. They asked for 280 volunteers to go farming and they got over 1000 . This means double rations and also exercise. We drew cards and I was lucky. Only from the rank of cpl, downwards were allowed to go working. It means 5 groups of 50 men. I was selected group commander for "Five Group", to look after the interests of the men. What a difficult job, hungry men at that, always grumbling and moaning.

30th January. Two majors in charge of us $\mathrm{S}$. Africans and 280 men moved off at 8 a.m. We marched to the station again and were put onto a train which arrived a few hours later at Foggia. We were then marched through the town to a small camp 2 miles away from the town and $\frac{1}{2}$ mile from the aerodrome. Here we were handed over to the Germans. We discovered we had been brought here under false pretences. It meant working for the Germans and not farming for which we had volunteered. The Germans brought us good food from their own kitchen, the same rations as the German soldier received, so we did not mind working for them now. They told us we had to build a road for them. Our RSM did not like the idea and asked to be taken to see a British officer to get permission. They did so, but 
they never brought him back. Once, again we were cut off from the outside world. The building of the road was not serious and was permitted under the Geneva Convention, the only problem being was that the road was to be built around the aerodrome. Anyway, we agreed to take a vote and the men decided to go on with the job. We carried on with the job and were very well treated by the Germans, and we were often given extra food and also given food by the contractors. We did no skilled work; only labour work. They called for tradesmen, but we told them that there were no tradesmen amongst us.

The ration scale here is (compare it with that of the Italians) - per man per day:

$\begin{array}{ll}\text { Potatoes } & -50 \text { grams } \\ \text { oats } & -21 \text { grams } \\ \text { coffee } & -9 \text { grams } \\ \text { sugar } & 2,5 \text { grams } \\ \text { salt } & -15 \text { grams } \\ \text { butter (1st grade Danish) } & -36 \text { grams } \\ \text { cheese } & -7 \text { grams } \\ \text { tea (Ersartz) } & -1 \text { gram } \\ \text { meat } & -56 \text { grams } \\ \text { jam } & -259 \text { grams } \\ \text { bread (black) } & -473 \text { grams }\end{array}$

No cig's - we still received our cig's from the Red Cross. Our narcols icsue was now 1 darrel per man per week which we received regularly. We were now living like fighting cocks, only we had to work 10 hours per day including Saturdays and 5 hours on Sundays.

A soap issue and letter-cards were made twice a week. We were allowed to write 36 words on the card and about 140 on the letter-card per week, to our families. German guards are good to us although they are not officially allowed to converse with us. One stuka pilot sgt used to bring me a small bottle of rum each day and hide it under a rock where I collected it.

On April 24th 1943 trouble started. The Germans instructed us to build hangers and runways on the aerodrome. So one morning when the German guard called us the $S / M$, myself and the other 4 group commanders stood together with the majority vote of the men to refuse to go on working, as that type of work was direct war work. The German S/M left and came back with a German Major who tried to threaten us. We still refused. Our S/M Patersen, a good man and a "sticker" was placed under close arrest and with two German escorts was marched off. No one knew where to. We heard 4 days after that he was locked in a cell. They tried to force us out to work by threats. We still refused. They then brought an Italian Major to talk to us. He also threatened us by saying we would be sent to a punishment camp. That never altered our feelings.

We had now built up our physique again and were full of cheek. We demanded the release of our S/Major. They released him there and then. He was badly treated in the cell, little food, no cig's. We asked if we could go farming for the Italians; permission was granted, and on the 6th May we were all moved off in batches of 50 to various farms. My group was moved to a farm about 25 miles from Foggia. The name of the town is Ceregnola. We were put into a small camp, nice barracks with barbed wire around. There were 24 Italian guards guarding 50 men. Here we worked 8 hours a day and rested on Sundays. We received no news here at all. All we knew was that our bombers were over often. We could see them, 200 to 300 at a time when they fly over our camp to bomb Foggia, the aerodrome we were supposed to work on - our luck that we left just in time! I bribed an Italian civilian with a packet of Red Cross coffee to bring me a newspaper and he took the chance. He brought our bread rations from town each day and placed the newspaper in the bread. We had a chap who learnt Italian and could read it well. He translated the paper each day. We followed the advances of our forces. Tunisia and Panteleria Island.

The work was not hard. We did weeding, harvesting, ploughing and hoeing. Then the good news came of the landing of the Allies on Sicily. Three of us immediately planned an escape, when the chance came. We tried to dig a hole through the wall, but the wall was of rock. We started saving tinned food. We worked out our bearings. We knew the stars. We knew it was still to early to escape, although we knew our forces were on their way. No one else knew of our plans. I was scared to tell anybody else in case somebody spoke out of turn. I thought when the time came I would warn all the men; giving everybody the same chance. I started selling Red Cross articles such as soap, tea, cocoa and meat to the Italians for lire. I knew we would need the money. Then the news came that Mussolini had been overpowered. Everybody, including the prisoners were happy. We thought the war would end in Italy. Everybody was disappointed when it didn't. 
We were getting articles of Italian uniforms so that we could escape in Ity uniforms. We could all speak a little Italian and thought we would pass as Itys. Then the news that Sicily had fallen. We were glad. We knew that in about one more month, we could expect in invasion of Italy. Stil we waited. We still had no plans of how to get out of camp. The camp was now better guarded Germans were massing troops nearby, A.A. guns and artillery. We were not far from the coast, about 6 miles. They evidently expected an Allied landing there, at Brendisi. Three days after the fall of Sicily on the 20th August, 1943, I received orders from the Camp Commandant, a Captain, that no man were to go out working, the reason being that we were moving the following morning north of Rome. Now we had to think fast. We were fenced in. How were we to get out? before morning? We had to leave at 6 a.m. on the 21 st August. Luc * was with us.

At 5 p.m. that afternoon an Italian foreman came into the camp. A barn was attached to this camp with huge doors which were kept locked, it was about 20 yards from the guards. He went into this barn to check the carts which were to transport us to the station the following morning. From the barn one could go through a back door leading away from the guards. There was a chance. One man slipped in unseen, and hid behind a tractor. Once inside he would open the doors from the inside. The Italian came out, locked the door and left the camp. We knew we now stood a chance of getting out of the camp. Still a risk. At 10 p.m. everybody had to be in the barracks and no one was allowed into the courtyard. The barn lead from the courtyard. Without telling anyone, the other 2 of us got our belongings ready and changed into the Italian uniforms. I had obtained Alex's uniform as well. At 9 p.m. I called all the men together and asked if anyone was interested in escaping. I told them our movements and plans. Nobody was interested with the exception of one man. I wrote down all their home addresses and said that if we got through I would notify their next-of-kin informing them of how they were when we left them. At 9.30 p.m. we moved one by one at intervals of 3 minutes, while other prisoners spoke to the guards to distract their attention. I went through last. We made a good getaway, without an alarm, only I forgot to bring the water bottles. We had only one among the four of us, and a few tins of Red Cross bully and salmon. We now made for the Alpine mountains as we had previously planned, about 70 miles away.
We depended on grapes and figs to live on, it fortunately being the right season for them.

To be away from behind barbed wire and guards after fourteen months in captivity, made one feel a free man again, but we still had a difficult task ahead of us. How long had we to wait? Our intention was to get to the mountains and follow the range down to the toe of Italy. There we hoped to meet our own forces.

After tramping at a brisk speed through oloughed ground and by passing a small village and dodging dogs, we intended walking not less than ten miles the first night. We knew that when they found us missing in the morning the alarm would be sounded. All the villages are immediately notified as well as the farmers, and a search would be made. Italy is so thickly populated that we stood the chance of being seen, so planned to walk only by night and "lay up" during the day.

After ploudıng about three miles trom our camp, we sat down in a vineyard for a rest. We had nc sooner sat down when a dark figure sprang on us from behind a tree, with a revolver in hand. We dashed off like lightning. He shouted "Alt" meaning "Halt". We then knew he was an Italian. We turned back and spoke Afrikaans to each other and explained in Ity to him that we were a German patrol looking for English paratroops. $\mathrm{He}$ apologised and we went on. Now we had to get away as far as possible.

After trekking miles, we looked for a good hiding place, to rest during the day. It was now 4.30 z.m. We cut our way into brambles and there we slept. The whole of the following day we had to lie quietly on our backs for $19 \mathrm{hrs}$, as Italians were passing within ten yards from us. We were close to a patch.

Ne had one tin of bully to eat among the four of us all day. That night at 9.30 p.m. we were on sur way again. We found delicious grapes and lad a good feed. We found some water later on and washed, then we were on our way again. After six miles through difficult country, valleys, nountains and rivers to cross, we found a good hide-out on the side of a mountain. There we rested for two days. We only walked by night between the hours of 9.30 p.m. to 5 a.m. Then we searched for a hide-out. In this way we caried on for days, each night covering a few niles, sometimes having very narrow escapes from being seen by both Germans and Italians. 


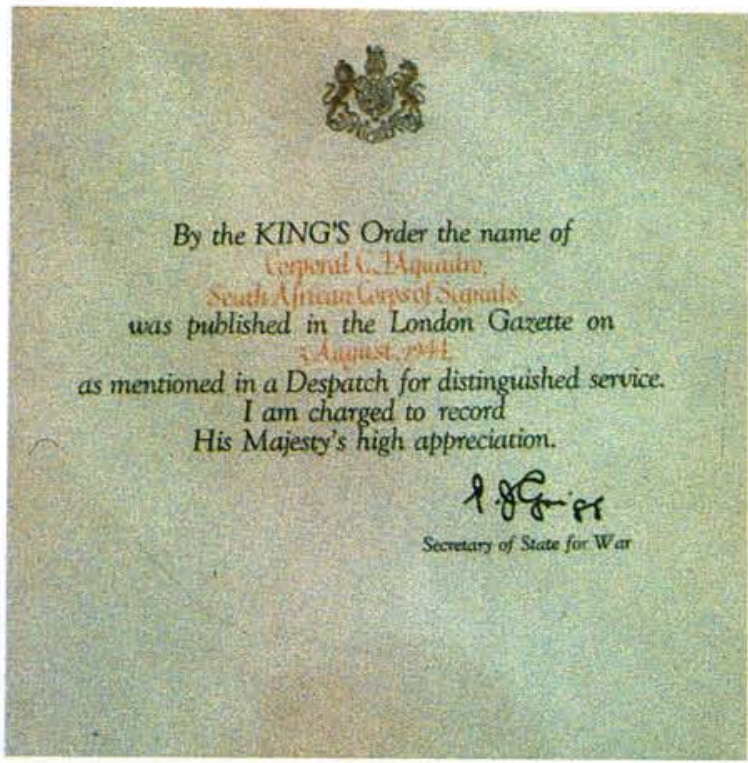

The "Mentioned in Despatches" awarded to Cpl Aquadro by the British authorities for a "brave escape from enemy territory". He also received the 1939-45 Star, Africa Star, War Medal 1939-45 with Oak Leaf, Africa Service Medal and the Efficiency Medal.

Our one hide-out was next to the main road which runs from Rome to Potenza, and we watched German transport pass all days. Our main diet now was figs, grapes, tomatoes, walnuts and occasionally we found apples.

On the 5th of September we had to cross a railway line guarded by Germans. It was a difficult task but we managed to get across unseen. Often, at night we could hear our bombers bombing in the distance. On numerous occasions when we struck rivers we had a good swim and a good wash. Our clothes were beginning to fall apart, ragged and torn and nothing to mend them with. It was the bushes in the mountains that wore them out. We saw a huge forest on the mountains which we headed for, intending lying up there for a week or so. We were now living in a cave with good "grazing" about three miles away - grapes, figs, tomatoes, walnuts and snails. It was now twenty eight days since we had escaped and we were getting weaker by the day. As we thought that our forces should have invaded by now, we were not prepared to give up, although on many occasions we felt inclined to do so.

We used to watch our bombers come over on daylight raids and be intercepted by German M.E.'s. A woodchopper used to pass close by our cave every morning, to work. One morning Chris and I decided to chat to him and tell him the truth and try and obtain news from him. It worked! He told us that the Allies had landed at five points. He felt very sorry for us and gave us food. Excitedly, we ran back to tell the others. We were all so over joyed - we hugged each other. He then told us where they had landed. It only meant getting past the Germans now and we would be in Allied lines again. The Allies were fighting in the capital of Potenza. We were living in the province about three miles from a village and our forces were now twenty five miles away from there. We could hear artillery duels from both sides. Our fighter planes flew close by, but we could not attract their attention.

On the 20th September Chris went down with malaria. As he was very ill, our Italian suggested that I see the mayor of the town who was proBritish and also a chemist and from whom I could obtain medicine for Chris. There were still Germans in the town but I decided to take a chance for Chris's sake. He was very ill.

The Italian brought me civilian clothes and a donkey and we then rode into the town. I was very worried that the Germans would recognise me as they passed us, fortunately they did not do so. When we saw the chemist I explained the position and he gave me the medicine Chris needed, and I went back. Chris and the other two were glad to see me. I had been away so long that they thought that I had been recaptured. I gave Chris the medicine and he improved.

On the 25th Sept a message was brought to me by the Italian from the Mayor of the town saying we were to come to the village as the Germans had evacuated the town and they were expecting the 8 th Army to arrive at 3 p.m. We were so thrilled we hugged each other. As we were on our way to the town a jeep passed us, followed by trucks - to our surprise and joy - having thought they were Germans - found it was a reccy of Canadians of the 8th Army. We just could not help ourselves and hugged them. They sent us to their " $Q$ " stores who fitted us out with kits. They were chasing Jerry up the main road, so we had to remain with them for seven days. They were marvellous to us.

From the time we escaped until we met the Canadians thirty six days had passed. The Canadians sent us back to Bari by truck. Chris was sent to hospital. At Bari we met the first S. African 3th Army Sig's. We were all so pleased to meet South Africans again. They fed us well, 


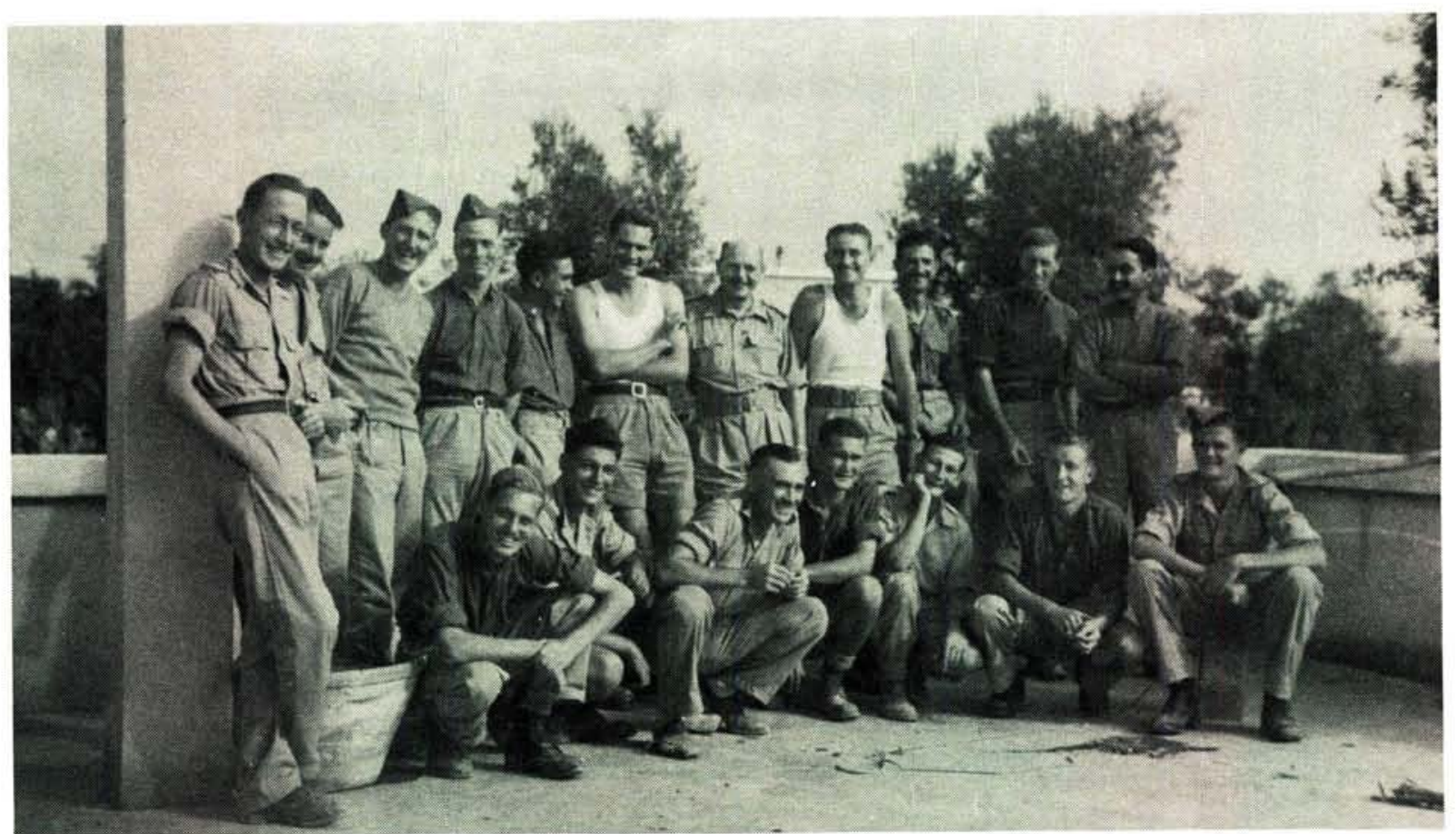

Escapees at Taranto (Toronto) Italy. In the middle of the back row is the chaplain flanked (in white vests) by Cpl Aquadro (right) and Bill Mason from Middelburg, Cape, who was one of the group of four who escaped with Cpl Aquadro.

gave us smokes and sent us by truck to Toronto (transit camp in Italy), where the rear 8th Army Sigs were stationed. We were met by Bruce Anderson, the war correspondent, and officers of the Army Sigs. They gave us a party and we celebrated well on champagne, whisky and beer. The following morning we recorded messages for broadcasting home.

We were sent to a camp in town where escaped P.O.W.'s were accommodated. All told we were forty-two South Africans. After paying and clothing us and doing all they could for us, we were put aboard a ship and sailed for Sicily. We disembarked and were taken to an aerodrome, where the Yanks flew us across to Cairo. In Cairo we were welcomed and given a marvellous time. From Cairo we were sent to a St. John's rest camp in Alexandria, and very well entertained there.

Ten days later on the 6th November, 1943 we flew down from Cairo and arrived in S. Africa on the 9th November. We were given two months non-recorded leave and one month recorded. Believe me, it was well-deserved.

I am now with 33 Lof $C$ Sigs DHQ., Pretoria and fortunately still $A 1$ and fit, ready to go back again.

I was lucky to get this diary through, as we were searched on numerous occasions, but I carried it in my boot.

- Mr Aquadro was a corporal when captured at Tobruk. He was demobilised at the end of the war. 